\title{
Ireland's Medieval Woodland: An archaeological approach to understanding long term patterns of wood use, management and exploitation
}

\section{Susan Lyons}

Department of Archaeology, UCC

Mayo, Roscommon, Derry, Newry, Trim, Roscrea, Adare, Kildare, Kilcullen, Cratloe, Youghal, Clonakilty, - what do these Irish place names have in common? They all derive from the name of a tree or a wood. Of the 16,000 townlands in Ireland, approximately 13,000 are named after trees. Root words expressive of woods, forests and trees include coil/coillte (wood); daire/daur (oak); coll (hazel); cuileann (holly); sail (willow); iúir/eo (yew), trom (elder) and beithe (birch), the earliest written records date to the seventh century A.D. In most cases, the woods that lent their name to places in Ireland have long gone, but through the uniqueness of Irish place names, we gain a fascinating insight into the high regard in which people in medieval Ireland held the humble tree.

\section{Historical roots}

It has long been the perception that Ireland was an extensively wooded country up until the seventeenth century. We know very little of the extant of Ireland's medieval woodland as no official records exist. At the time of Civil Survey of A.D. 1654-56 many of the townlands bearing the name of woods were relatively treeless. During the early medieval period (A.D. 400-1100), woodland was already a distinct, valued zone in a generally open agricultural landscape from at least the fifth century A.D. To chart how woods fluctuated in the past, pollen analysis is primarily used to interpret past ecological change. Pollen analysis is a robust technique for reconstructing former vegetation composition and different types of human land use (e.g. agriculture, grazing and woodland management) using plant microfossils (pollen grains and spores) that have been preserved in peatlands and lake sediments.

Traditionally, trees played a pivotal role both practically and spiritually in the lives of the early Irish people as many historical references testify. The role of woodlands in the medieval social system can be observed through the Brehon Laws, the statutes which governed Gaelic life in medieval Ireland from the seventh to the seventeenth century A.D. While the legal information pertaining to trees is limited and fragmented in these documents, the scholarly works of A. T. Lucas, D. A. Binchy and Fergus Kelly have been in- 
strumental in providing a solid foundation for continuing research on this subject. Woods were integral to medieval daily life, a multi-layered ecosystem providing sources of firewood, charcoal, timber, food, medicine and even shelter in times of unrest. If communities mismanaged their woodland resources they were in danger of losing their self-sufficiency. Trees were recognised as objects of economic importance and the eighth-century document, Bretha na Comaithchesca (Law of the Neighbourhood), served to protect woodland and regulate wood use. Strict fines were imposed if trees of certain value were cut down or damaged without permission. Trees were classified on a hierarchical ranking, based on functionality (timber quality and fruit production), cultural significance and their stance as boundary markers:

Airig Fedo (Nobles of the Wood): oak, hazel, holly, yew, ash, apple

Aithig Fedo (Commoners of the Wood): alder, willow, hawthorn, birch, elm, wild cherry

Fodla Fedo (Lower Divisions of the Wood): blackthorn, elder, juniper, spindle, whitebeam

Iosa Fedo (Bushes of the Wood): bracken, gorse, bramble, heather, wild rose

Trees also abound in Irish folklore, a frequent theme being sacred trees or bile. Sacred trees were found at holy wells, churches were constructed at the site of sacred trees and groves and cultural ceremonies and royal inaugurations were often performed at a specific tree (Fig. 1). The legal protection of these revered features was also documented in the eighth-century poem, Ma be rí rofesser, from the law tract Críth Gablach which reads: "A danger from which there is no escape is the penalty for felling a sacred tree" (translation D. A. Binchy). To destroy such trees would have therefore been an act imbued with wider religious and political connotations, and their veneration suggests a deep-rooted sense of cultural identity and place.

\section{Can we see the wood for the trees?}

To date, the history, use and exploitation of Ireland's medieval woodland has been largely reconstructed using historical records and pollen analysis. Despite these sources, wood use and woodland history for medieval Ireland is sporadic and discussed in broad and generic terms. Changes to local woodland were rarely recorded, unless they had a social or economic impact and local patterns of wood use and selection practices are still unknown. Evidence for explicit woodland management practices prior to the twelfth century is still elusive and continues to be debated amongst historians and archaeologists alike. While seminal work on early Irish law tracts by Fergus Kelly quotes compelling literary evidence for early medieval woodland management in the form of coppicing, the archaeological remains for direct management strategies is still under-represented. Timber, firewood and 


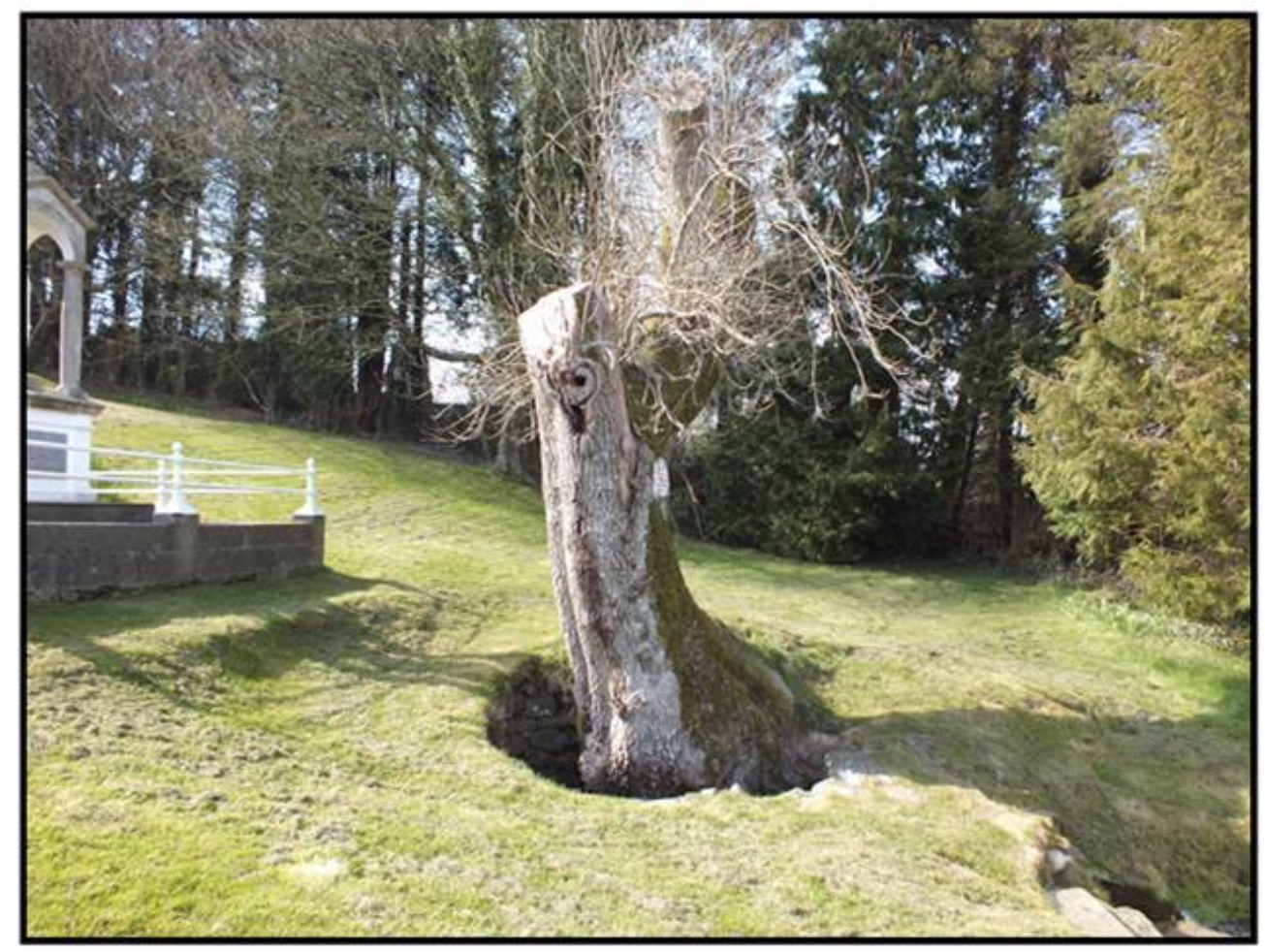

Figure 1: St. Cuan Well, Tobarchuain, Co.Waterford. An ash tree growing from base of the well. Image: Louise Nugent.

underwood cannot be fully discerned using the literary sources, which makes wood selection and procurement difficult to interpret. Woodland reconstruction using the medieval Irish records is also highly problematic as these are often chronologically and geographically fragmented.

Pollen investigations have shown that more diverse woodland existed in Ireland than previously recognised. Despite this, very few pollen studies for the medieval period provide unequivocal information regarding factors affecting local woodland and seem to lack sufficient chronological resolution to identify precise rates of change. Regional woodland patterns are often extrapolated to local landscapes, without considering other variables, such as topography, geology and local soil conditions. Despite the qualitative (historical) and quantitative (pollen) methods currently used for charting wood use and woodland change for medieval Ireland, it is apparent that an holistic approach integrating different datasets is required to elucidate many aspects of medieval wood use, management and exploitation.

\section{An archaeological approach}

So what can a subject like archaeology offer to woodland research and can it contribute new knowledge to Irish medieval studies? My research will identify and analyse wood 
charcoal recovered from archaeological sites as a new approach to understanding past woodland ecology and human activity. Archaeological charcoal is essentially the remains of the woods used by people in the past and represents the only body of material that has not been coherently assessed with regard to Irish medieval woodland. The increase in commercial archaeological excavation in Ireland over the last fifteen years has generated a huge charcoal dataset from a variety of sites that requires more detailed attention. Charcoal is the most ubiquitous type of plant macro-remains recovered from archaeological sites in Ireland, but often the most neglected. It represents (a) the product of purposeful human activity associated with domestic/industrial activity (fuel; firewood; charcoal production) and (b) events associated with the burning or destruction of a building or structure. It is a robust material, survives well in a variety of environmental conditions and is the only source of woodland reconstruction in dry land areas. Improvements in methodologies and sampling strategies over the last twenty years have also seen it emerge as a viable tool in reconstructing past woodlands.

Charcoal is uniquely placed to tease out specifics on wood selection, thus offering new information on medieval woodland composition, management and resource use. An assessment of this material will produce a comparative analysis of wood use between different medieval settlement types and associated activities. The role of lesser known wood species, species of low economic value and the presence of non-native woods will also be better represented. Charcoal also provides a high resolution site-related record of local woodland at a temporal scale congruent with the archaeological context itself. The analysis of charred wood is of special interest in regions where pollen analysis is unsuited, such as dry land zones, providing the only source for woodland reconstruction in these areas. Pollen sampling sites are confined to lake sediments and peatlands, thus limiting the range of areas for potential woodland reconstruction.

Very few pollen studies for the medieval period also provide unequivocal information regarding factors affecting local woodland and lacks sufficient chronological resolution to identify precise rates of ecological change. An increase in archaeological charcoal studies in Ireland and abroad has revealed that wood exploitation was more closely dependent on the local wood availability, something that pollen analyses cannot identify in isolation. This research can therefore offer new information on woodland change, including periods of clearance and regeneration, through secondary woodland and hedgerow indicators.

\section{Methodology}

The direct exploitation of woodland resources is best understood by analysing the physical wood remains themselves through an integrated approach. The first step of my research is to carry out wood species identification using microscopic techniques to generate a list of the woods being utilised (Fig. 2a). Other dendrological analyses, such as identifying 


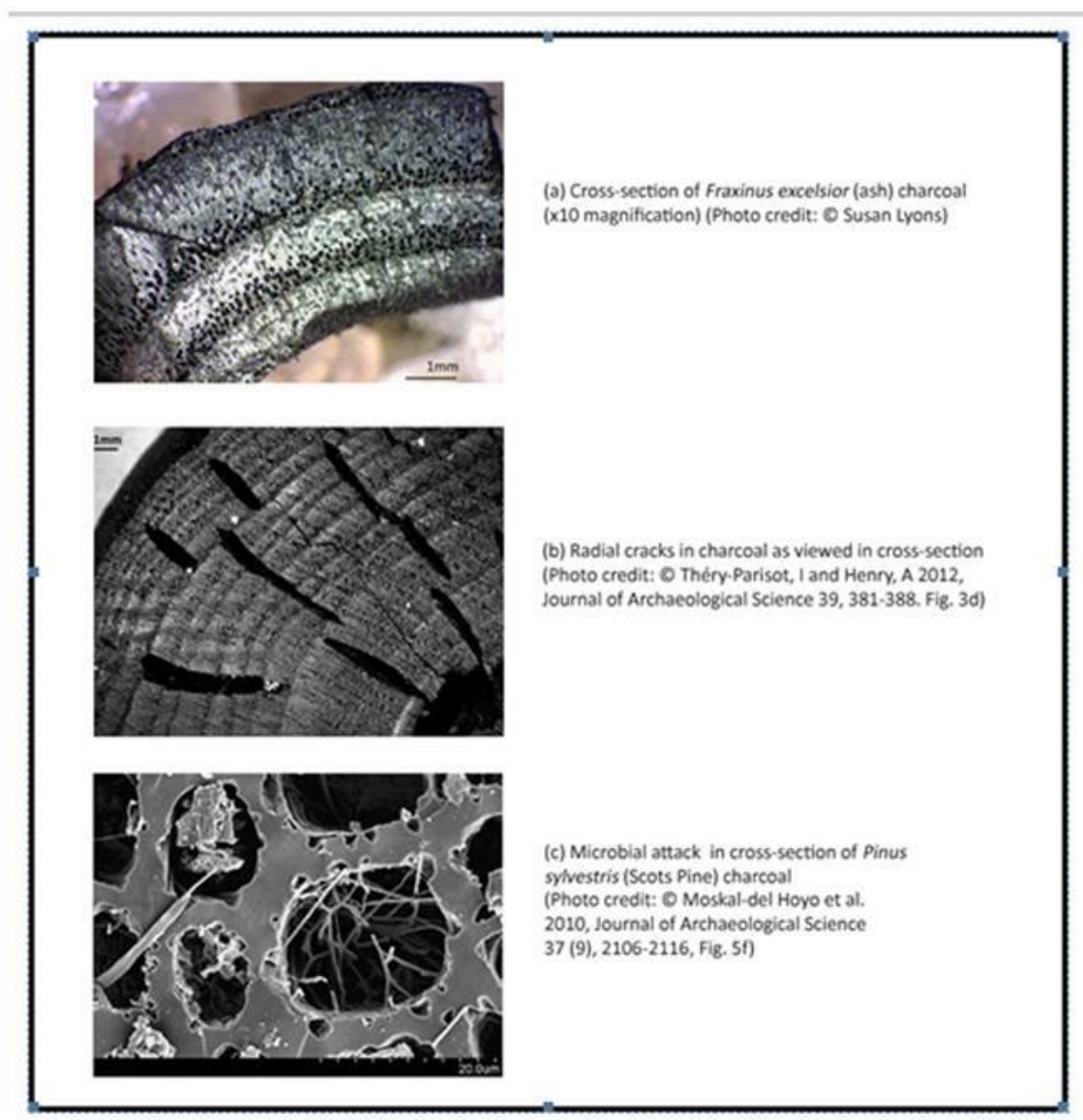

Figure 2: Microscopic wood charcoal identification and dendrological analysis

radial cracks (Fig. 2b) and microbial attack (Fig. 2c) will also be performed. This provides information on timber quality and can reveal whether wood was collected fresh or was stored. Assessing the curvature of annual growth rings will determine if small, medium or large wood was used, which will potentially help understand woodland management practices, firewood acquisition and collection strategies.

The data will be entered into a specifically designed database called WODAN (www.wodan.ie). WODAN was created in Ireland in 2010 and is the first standardised European online database for archiving archaeological wood and charcoal. The design has been developed to allow for comparable analysis and query building, which facilitates rigorous manipulation of large datasets for statistical analysis. My research will be the first to use the database to analysis charcoal assemblages specifically from medieval Irish sites. WODAN can also be geo-referenced, which will aid the second step of my research, to preform spatial analyses for wood used at each focus area selected, allowing comparisons to be made across different geographical zones. The results will be integrated and synchronise with the medieval pollen and historical data allowing for a quantitative and qualitative evaluation of the results. 


\section{Study Areas}

A series of medieval sites from three catchment areas in Co. Tipperary, Co. Kilkenny and Co. Meath will form the focus for this research. The sites range in date from the early medieval (400 to $1100 \mathrm{AD}$ ) to the late high/late medieval (1100 to $1550 \mathrm{AD}$ ) and comprise a variety of urban, rural and ecclesiastical settlement. Charcoal identifications have been carried out on 30 sites by the author and a subset assemblage from each has been selected for further dendrological study.

These areas of settlement reflect social organisation, where wood resources would have been more controlled. Understanding wood collection practices will therefore help interpret patterns of woodland management and procurement at a site. Charcoal samples from well stratified deposits representing explicit archaeological activity will be targeted:

Structural activity (post-holes)

Domestic activity (hearths; roasting pit; rubbish pits)

Manufacturing activity (kilns; metalworking; charcoal production pits)

\section{Preliminary Results}

To date, results are revealing that wood species of high economic value (oak, ash and hazel) were being used for building and specialised activities, such as metalworking and charcoal production. There are slight changes in wood composition between early and later medieval dated sites at local level, which could reflect cultural or environmental factors. An interesting observation thus far is the notable presence of pomaceous fruitwood (apple/pear/hawthorn/rowan) and cherry-woods, which may be indicators of orchards or garden plots. The history of orchards for medieval Ireland is relatively scant, so this project can potentially offer new insights into this subject. Pomaceous fruitwoods are also under-represented in the pollen record, so wood charcoal provides the only direct evidence that these species existed at a site.

\section{Conclusion}

Using archaeological charcoal within a multi-disciplinary framework, this research will provide a new dataset for research into Ireland's woodland history. The project will generate new hypotheses for how cultural and environmental factors influenced medieval wood use and establish a new paradigm for recording patterns of wood exploitation. It will also contribute to existing proxies for woodland reconstruction and be uniquely placed to provide a rigorous theoretical grounding for future archaeological, historical and palaeoecological integration. Woodland resources, albeit prosaic, were a vital component of Ire- 
land's medieval economy. Past patterns of agriculture, settlement, management systems and secondary regrowth has severely impacted on Ireland's woodland and has altered its natural landscape. Therefore, to understand such changes we must look to the past to see how people interacted with these local resources.

The author would like to acknowledge the Irish Research Council (IRC) as the funding body for this project. Thanks also to Dr Louise Nugent, Dr Isabelle Théry-Parisot and Dr Magdelena Moskal-del Hoyo for the use of images and to my supervisor Dr Benjamin Gearey and the staff of UCC Archaeology Department for their support. 